\title{
KARAKTERISTIK BAHASA GURU BIMBINGAN DAN KONSELING PADA SMP KECAMATAN BANDAR BARU, KABUPATEN PIDIE JAYA.
}

\author{
Hayatun Rahmi \\ Program Studi Pendidikan Bahasa Indonesia \\ Fakultas Keguruan dan Ilmu Pendidikan \\ Universitas Jabal Ghafur
}

\begin{abstract}
This study aims to describe the characteristics of language teachers BK at SMP Bandar Baru District, Pidie Jaya District. The research assumptions are (1) the issue of teacher language characteristics of BK at SMP Kecamatan Bandar Baru Pidie Jaya is very important, (2) the language characteristics of teachers BK can improve morale and student achievement through the provision of guidance and counseling services, (3) this study can be used as material reference in the provision of counseling and guidance services in schools. The method used in this research is descriptive method with qualitative approach. Data source in this research is BK teacher at SMP Kecamatan Bandar Baru, Pidie Jaya District. The data in this study are the speeches produced by the teacher BK. to collect the data of researchers using the technique refer (observation). Research actions are conducted in three stages: (1) data reduction stage consisting of data processing, data identification, and data classification, (2) presentation and explanation of data, (3) phase of conclusion and data verification. The result of the research shows that the characteristics of the language of teachers of BK at SMP Kecamatan Bandar Baru Pidie Jaya District are as follows, first in terms of direct verbal expression found two aspects of direct verbal expressions that are (1) aspect mention feeling and give name to feeling, (3) the form of action you want done. Secondly, from the aspect of the verbal expression it is not immediately found seven aspects of expression, that is (1) commanding, (2) asking, (3) accusing, (4) insinuating, (5) praising, (6) criticizing, (7) using a designation. It was concluded that the characteristics of BK teacher's language at Bandar Baru junior high school, Pidie Jaya district have used good language characteristic but need many improvement.
\end{abstract}

Keywords: Language Characteristics of BK Teachers, Teachers BK SMP Kecamatan Bandar Baru Pidie Jaya

\begin{abstract}
ABSTRAK
Penelitian ini bertujuan untuk mendeskripsiskan karakteristik bahasa guru BK pada SMP Kecamatan Bandar Baru, Kabupaten Pidie Jaya. Asumsi penelitian adalah (1) persoalan karakteristik bahasa guru BK pada SMP Kecamatan Bandar Baru Pidie Jaya sangat perlu diperhatikan, (2) karakteristik bahasa guru BK dapat meningkatkan moral dan prestasi siswa melalui pemberian layanan bimbingan dan konseling, (3) kajian ini dapat dijadikan bahan acuan dalam pemberian layanan bimbingan dan konseling di sekolah. Metode yang digunakan dalam penelitian ini adalah metode deskriptif dengan pendekatan kualitatif. Sumber data dalam penelitian ini adalah guru BK pada SMP Kecamatan Bandar Baru, Kabupaten Pidie Jaya. Data dalam penelitian ini adalah tuturan-tuturan yang dihasilkan oleh guru BK. untuk mengumpulkan data peneliti menggunakan teknik simak (observasi). Tindakan penelitian dilakukan dalam tiga tahap: (1) tahap reduksi data yang terdiri dari mentrankrip data, identifikasi data, dan klasifikasi data,(2) tahap penyajian dan penjelasan data, (3) tahap penarikan simpulan dan verifikasi data. Hasil penelitian menunjukkan bahwa karakteristik bahasa guru BK pada SMP Kecamatan Bandar Baru Kabupaten Pidie Jaya adalah sebagai berikut, pertama dari segi ungkapan verbal langsung ditemukan dua aspek ungkapan verbal langsung yaitu (1) aspek menyebutkan perasaan dan memberikan nama pada perasaan, (3) aspek menunjukkan bentuk tindakan yang ingin dilakukan. Kedua, dari aspek ungkapan verbal tidak langsung ditemukan tujuh aspek ungkapan, yaitu (1) memerintah, (2) bertanya, (3) menuduh, (4) menyindir, (5) memuji, (6) mencela, (7) memakai sebutan. Disimpulkan, karakteristik bahasa guru BK pada SMP Kecamatan Bandar Baru, Kabupaten Pidie Jaya sudah menggunakan karakteristik bahasa yang baik namun perlu adanya banyak peningkatan.
\end{abstract}

Kata Kunci: Karakteristik Bahasa Guru BK, Guru BK SMP Kecamatan Bandar Baru Pidie Jaya 


\section{Pendahuluan}

Penelitian ini berkenaan dengan kajian bahasa yaitu kajian tentang karakteristik bahasa guru bimbingan dan konseling pada SMP Kecamatan Bandar Baru, Kabupaten Pidie Jaya. Penelitian ini dilandasi oleh beberapa dasar pemikiran sebagai berikut. Bahasa merupakan salah satu alat komunikasi yang berupa simbol yang dihasilkan oleh alat ucap manusia. Bahasa adalah sistem lambang bunyi yang arbitrer, yang digunakan oleh anggota suatu masyarakat untuk bekerja sama, berinteraksi, dan mengidentisifikasi diri (KBBI, 2005:88).

Berbicara tentang interaksi sosial tentu semua itu ada hubungannya dengan penggunaan bahasa antarpenutur khususnya penggunaan bahasa yang melibatkan kesesuaian pembicaraan dengan pendengaran dalam suatu percakapan. Penggunaan bahasa tersebut dianggap sebagai fungsi bahasa untuk membuka saluran komunikasi dan membangun hubungan antara warga masyarakat khususnya warga masyarakat di lingkungan sekolah. Penggunaan bahasa di lingkungan sekolah sangat perlu diperhatikan karena sekolah merupakan salah satu sarana pendidikan di mana peserta didik dapat menuntut ilmu.

Berdasarkan kenyataan tersebut nampaknya ada sesuatu hal yang menarik untuk dikaji yaitu berkaitan dengan bahasa yang digunakan guru BK. Biasanya penelitian karakteristik bahasa guru BK ini dikaitkan dengan kelas sosial karena karakteristik bahasa guru BK ini berkaitan erat dengan pelaku pengguna bahasa. Disadari atau tidak kelas sosial itu ada dalam konteks apapun dan dimanapun, termasuk dalam konteks lingkungan sekolah. oleh karena itu, dalam penelitian ini peneliti ingin melihat karakteristik bahasa guru BK yang dipertukarkan antara guru BK dan siswa dalam proses pemberian layanan bimbingan dan konseling.

\section{Kajian Pustaka}

Karakteristik berasal dari bahasa Inggris, yaitu characteristic yang berarti mengandung sifat khas dari sesuatu. Chaplin (2006) menyatakan bahwa karakteristik merupakan sinonim dari kata karakter, watak, atau sifat yang khas yang dimiliki oleh suatu objek. Oleh karena itu, dapat dikatakan bahwa karakteristik bahasa merupakan sifat atau ciri khas yang dimiliki oleh suatu bahasa.
Bahasa adalah sebuah sistem simbol lisan yang arbitrer yang dipakai oleh anggota suatu masyarakat bahasa untuk berkomunikasi dan berinteraksi antar sesamanya, berlandaskan pada budaya yang mereka miliki bersama (Djardjowidjodjo, 2008:10). Sejalan dengan pendapat tersebut Kridalaksana (dalam Chaer, 2007:32) "Bahasa adalah sistem lambang bunyi yang arbitrer yang digunakan oleh para anggota kelompok sosial untuk bekerja sama, berkomunikasi, dan mengidentifikasi diri. "Oleh karena itu, dapat dikatakan bahwa bahasa adalah sebuah sistem lambang bunyi ujaran yang digunakan oleh masyarakat untuk berkomunikasi antar sesamanya.

Sistem bahasa berupa lambang-lambang bunyi, yang lazim disebut bunyi ujar atau bunyi bahasa. Setiap lambang bahasa melambangkan sesuatu yang disebut makna atau konsep. Sejalan dengan definisi bahasa yang telah dikemukakan oleh beberapa pakar, Chaer (2007:33) menyatakan "Bahasa memiliki sifat, ciri, atau karakteristik tersendiri, yaitu (1) bahasa sebagai sistem, (2) bahasa sebagai lambang, (3) bahasa berupa bunyi, (4) bahasa itu bermakna, (5) bahasa bersifat arbitrer, (6) bahasa bersifat konvensional, (7) bahasa bersifat produktif, (8) bahasa itu unik, (9) bahasa bersifat universal, (10) bahasa bersifat dinamis, (11) bahasa bersifat manusiawi, (12) bahasa itu bervariasi, (13) ragam bahasa juga menunjukkan kebervariasian suatu bahasa.

Bahasa merupakan alat untuk berinteraksi atau alat untuk berkomunikasi, dalam artian bahasa digunakan untuk menyampaikan pikiran, gagasan, konsep atau perasaan. Oleh karena itu, bahasa memiliki fungsi dan kedudukan penting dalam kehidupan manusia. Wardhough (dalam Chaer dan Leonie, 2010:19) menyatakan bahwa bahasa berfungsi sebagai alat komunikasi manusia, baik itu secara tertulis maupun secara lisan. Selanjutnya, Fishman (dalam Chaer dan Leonie, 2010:20) juga mengemukakan bahwa fungsi bahasa itu dapat dilihat dari sudut penutur, pendengar, topik, kode, amanat, dan pembicara.

Pada poin kedua belas dari karakteristik bahasa sudah disebutkan bahwa bahasa itu bervariasi. Kevariasian bahasa terjadi karena anggota masyarakat penutur bahasa itu sangat beragam, dan bahasa itu sendiri digunakan untuk keperluan yang beragam pula. Rokhman (2015:15) menyatakan bahwa variasi bahasa dapat dibedakan atas beberapa jenis, yaitu variasi bahasa dari segi sarana pemakaiannya 
dan dari segi tingkat keresmian situasi pemakaiannya. Selanjutnya, Chaer dan Leonie (2010:82-95) juga membedakan "Jenis variasi bahasa dalam beberapa jenis, di antaranya adalah sebagai berikut. (1) Variasi dari segi penutur, (2) Variasi Bahasa dari Segi Pemakaian, (3) Variasi dari Segi Keformalan dan, (4) Variasi dari Segi Sarana.

Berdasarkan uraian tentang variasi bahasa yang telah dikemukakan di atas dapat disimpulkan bahwa variasi bahasa dapat terjadi karena adanya perbedaan dari segi tempat, waktu, pemakai, situasi, dan dialek yang dihubungkan dengan sapaan, status, dan pemakaian bahasa itu sendiri. Oleh karena itu, berdasarkan jenis variasi bahasa tersebut guru termasuk salah satu pemakai variasi bahasa karena guru merupakan salah satu pengguna bahasa yang memilki tempat dan mitra tutur yang khas. Penggunaan bahasa oleh guru tidak hanya berfungsi sebagai alat untuk menyampaikan pesan tetapi juga berfungsi sebagai pemerolehan bahasa terhadap siswa. Selain dipakai untuk berkomunikasi dengan siswa penggunaan bahasa oleh guru juga berfungsi untuk perkembangan kemampuan berbahasa siswa. Dengan kata lain, bahasa yang dipakai oleh guru memiliki perbedaan dengan bahasa yang dipakai oleh penutur lain. Hal ini juga serupa dengan bahasa yang digunakan guru BK yang memiliki ciri atau sifat tersendiri.

Membangun hubungan dalam konseling merupakan langkah pertama dalam proses bimbingan dan konseling. Pada saat membangun hubungan dalam konseling hal utama yang harus diperhatikan adalah komunikasi karena komunikasi merupakan hal yang akan menentukan proses konseling berjalan dengan baik. Bimbingan dan konseling merupakan suatu proses yang melibatkan hubungan dan komunikasi yang interpersonal, yang berarti bahwa kaidah-kaidah yang berlaku dalam komunikasi juga berlaku dalam konseling.

Berbicara tentang komunikasi tentu semua itu ada kaitannya dengan keterampilanketerampilan berbahasa. Adapun keterampilan berbahasa yang berkaitan dengan konseling adalah keterampilan mendengarkan. Keterampilan mendengarkan juga merupakan hal yang sangat penting dalam konseling karena dalam proses konseling keterampilan mendengarkan merupakan kemampuan dasar yang harus dimiliki oleh konselor.

Selain keterampilan mendengarkan, komunikasi dalam konseling juga melibatkan aspek bahasa verbal dan nonverbal guna mencapai pemahaman yang seutuhnya terhadap apa yang disampaikan konseli. Pearson (dalam Lesmana, 2006:106) mendefinisikan komunikasi verbal sebagai the processes of exchanging meaning through the use of words. Berarti ada pertukaran kata-kata. Selanjutnya, Pearson (dalam Lesmana, 2006:108) juga mendefinisikan komunikasi nonverbal sebagai the process of exchanging meaning through all means that are nonverbal. Berdasarkan kedua pengertian aspek bahasa verbal dan nonverbal tersebut seorang konselor harus mendengarkan konseli dengan memperhatikan apa yang disampaikan melalui kata-katanya (yaitu aspek verbal) dan juga aspek nonverbal (yaitu bahasa tubuh, nada suara, ekspresi wajah, gerakan, dan lain-lain).

Menurut Hackney dan Cormier (dalam Lesmana, 2006:109) tingkah laku nonverbal yang diasosiasikan dengan positive regard untuk orang lain adalah: nada suara: lembut, menentramkan, ekspresi wajah: tersenyum, menunjukkan minat; posture: relax, condong ke arah orang yang di ajak bicara; kontak mata: melihat langsung ke mata orang lain; gestures: open, welcoming; kedekatan fisik: dekat; sentuhan: lembut dan diskrit.

Winkel dan Sri Hastuti (2007:246) juga mengatakan bahwa perasaan yang dikomunikasikan oleh konseli juga dapat diungkapkan dengan kata-kata (secara verbal) dan dengan isyarat-isyarat yang tidak berbentuk bahasa (secara nonverbal). Ungkapan verbal dan nonverbal kedua-duanya dapat langsung, dapat juga secara tidak langsung. Dalam ungkapan verbal langsung orang mendeskripsikan perasaannya dengan salah satu cara di antara empat cara berikut ini, yaitu: (1) Menyebutkan perasaan atau memberikan nama pada perasaan yang dialami, misalnya "Saya merasa marah", "Saya merasa gembira"; (2) menggunakan kiasan perasaan, misalnya "Serasa digigit semut"; (3) menunjukkan bentuk tindakan yang ingin dilakukan,misalnya "Rasanya ingin menjotos hidungmu"; (4) menggunakan kiasan kata-kata, misalnya "Saya merasa seperti layinglayang putus benang". Dalam cara ini perasaan disadari, diterima sepenuhnya sebagai miliknya sendiri dan dirumuskan secara jelas, sehingga orang lain dapat mengetahui perasaan apa yang sedang dialami (perasaan penampang atau surface feeling)

Selanjutnya dalam ungkapan verbal tidak langsung orang tidak mendeskripsikan perasaannya, tetapi tercetus dalam macam ungkapan yang digunakan, yaitu: (1) mencap atau memberikan cap verbal, misalnya "Huh, 
setan kau", "Anjing kau"; (2) memerintah, misalnya "Enyahlah dari sini", "Bukalah matamu itu!"; (3) bertanya, misalnya kepada orang yang datang terlambat, "Lho, jam berapa sekarang?", kepada orang yang berbicara tanpa berpikir, "waduh, pikiranmu di mana?"; (4) menuduh, misalnya "Kau sekarang ini acuh takk acuh padaku"; (5) menyindir, misalnya "Nah...dia kan anak orang yang besar", "Ah, indah benar tulisanmu"; (6) memuji, misalnya "Kau ini cakep lho!", "Saya salut dengan hasil usahamu"; (7) mencela, misalnya "Kau sungguh keterlaluan!", 'Goblok benar kamu ini”; (8) memakai sebutan, misalnya "Si Cebol!", "Si Jangkung!"

Winkel dan Sri Hastuti juga mengatakan selain ungkapan yang disebutkan di atas, perasaan juga dapat dicetuskan melalui aneka gejala vocal yang merupakan suatu aspek implisit pada berbicara (paralinguistic phenomena), seperti nada suara, tinggi rendahnya suara, kecepatan berbicara, lamanya berbicara, lembut kerasnya suara, dan saat-saat diam pada waktu berbicara. Bahkan keseluruhan konteks dan hubungan antara kata-kata serta beberapa kalimat dapat mengungkapkan suatu perasaan. Jadi, berdasarkan pendapat Hackney dan Cormier (dalam Lesmana), dan Wingkel dan Sri Hatuti tersebut seorang konselor yang berperan sebagai guru BK tentu harus memiliki keahlian-keahlian dalam berkomunikasi yang dilihat dari aspek bahasa verbal dan nonverbal ketika hendak melakukan proses bimbingan dan konseling di sekolah. Hal tersebut harus betulbetul diperhatikan oleh guru BK guna memperoleh hasil yang maksimal dan peserta didik pun akan menjadi pribadi yang baik di masa yang akan datang. Oleh karena itu, dalam proses konseling sangat pentinglah konselor memastikan lebih dahulu apakah penafsirannya terhadap ungkapan perasaan secara implisit, baik melaui bahasa verbal maupun bahasa nonverbal, tepat atau tidak (perception check).

\section{Metode Penelitian}

Metode yang digunakan dalam penelitian ini adalah metode deskriptif dengan pendekatan kualitatif. Metode deskriptif-kualitatif ini digunakan untuk melihat gambaran tentang bagaimana karakteristik bahasa guru BK dalam berkomunikasi dengan siswa pada SMP Kecamatan Bandara Baru, Kabupaten Pidie Jaya.
Merujuk pada pemilihan judul penulisan laporan penelitian ini, pelaksanaan penelitian dilakukan diwilayah kerja Dinas Pendidikan Kabupaten Pidie Jaya yaitu di Kecamatan Bandar Baru. Adapun pemilihan lokasi tersebut disebabkan jumlah guru BK sudah merata disetiap SMP Kecamatan Bandar Baru.

Data yang dikumpulkan dalam penelitian ini melalui observasi, yaitu tuturan-tuturan yang dihasilkan oleh guru BK. Tuturan-tuturan yang dimaksudkan dalam penelitian ini adalah tuturan guru selama proses pemberian bimbingan dan konseling terhadap siswa. Tuturan yang dijadikan sebagai data penelitian difokuskan pada tuturan karakteristik bahasa guru BK dalam proses pemberian bimbingan dan konseling.

Sumber data dalam penelitian ini adalah guru BK pada SMP Kecamatan Bandar Baru, Kabupaten Pidie Jaya, tahun pelajaran 2014/2015. Untuk memperoleh data dan hasil data yang lebih terfokus dalam penelitian ini maka peneliti mengambil sumber data dengan teknik purposive sampling.

Teknik pengumpulan data yang digunakan dalam penelitian ini adalah metode simak (observasi). Mahsun (2005:90) mengatakan bahwa metode simak merupakan metode yang digunakan untuk memperoleh data yang dilakukan dengan cara menyimak penggunaan bahasa. Metode simak juga memiliki teknik dasar yang berwujud teknik sadap. Teknik sadap disebut sebagai teknik dasar dalam metode simak karena pada hakikatnya penyimakan diwujudkan dengan penyadapan.

Teknik analisis data dalam penelitian ini didasarkan pada pendapat Miler \& Huberman (Sugiyoyono, 2010:337) yang terbagi dalam tiga tahap yaitu (1) tahap reduksi data, (2) tahap penyajian data, dan (3) tahap penarikan simpulan dan verifikasi. Pereduksian data dilakukan dengan cara mentranskripkan tuturan guru, mendaftarkan tuturan guru yang dianggap penting sebagai data dan memilah data sesuai rumusan masalah. Proses selanjutnya adalah 
penyajian data dengan mendeskripsikan hasil analisis data kemudian menginterpretasikan data. Langkah terakhir peneliti melakukan penarikan kesimpulan melalui pembahsan hasil analisis data. Jadi, berdasarkan pendapat yang telah dikemukan di atas, langkah-langkah yang dilakukan dalam menganalisis data adalah sebagai berikut.

(1) Mentranskrip tuturan guru BK dalam kegiatan pemberian bimbingan dan konseling terhadap siswa yang telah direkam berupa data lisan ke dalam data tertulis.

(2) Mengidentifikasi data berdasarkan jenis karakteristik bahasa guru BK.

(3) Mereduksi data, yaitu dengan memilih data yang memiliki karakteristik bahasa guru BK.

(4) Mengklasifikasi (mengelompokkan) data berdasarkan jenis karakteristik bahasa guru BK.

(5) Mendeskripsikan jenis karakteristik bahasa guru BK dalam proses bimbingan dan konseling berdasarkan hasil analisis data.

(6) Menginterpretasikan data karakteristik bahasa guru BK untuk memberikan penafsiran dan memberikan pendapat sesuai dengan katagori permasalahan.

(7) Menyimpulkan hasil analisis data

\section{Hasil Penelitian dan Pembahasan \\ Menyebutkan Perasaan dan Memberikan Nama pada Perasaan}

Berdasarkan data yang diperoleh, bahasa guru BK pada SMP Kecamatan Bandar Baru, Kabupaten Pidie Jaya memiliki karakteristik bahasa yang baik. Dalam tuturan tersebut ditemukan empat tuturan yang tergolong ke dalam ungkapan verbal langsung aspek menyebutkan perasaan dan memberikan nama pada perasaan yang digunakan guru BK dalam proses pemberian layanan bimbingan dan konseling.

Penggunaan aspek menyebutkan perasaan dan memberikan nama pada perasaan terdapat pada contoh (1), (2), dan (3) pada data tiga dan contoh (1), (2). Dan (3) data empat. Pada contoh (1) dan (2) data tiga guru BK menyebutkan perasaannya dengan ungkapan bahwa guru BK merasa malu dengan sifat anak didiknya yang tidak jujur atau berani dalam memberikan kebenaran informasi. Contoh (3) data tiga guru BK menyebutkan perasaannya dengan ungkapan rasa kagum dan gembira terhadap sifat anak didiknya yang mau mengakui kesalahannya dan berjanji tidak akan mengulanginya lagi.

Pada contoh (1), (2), dan (3) data empat guru BK menyebutkan perasaannya dengan ungkapan bahwa guru BK merasa tidak senang dengan sifat anak didiknya yang suka alpa, berbohong, dan tidak jujur terhadapp gurunya. Berdasarkan data tersebut dapat dikatakan bahwa guru BK pada SMP Kecamatan Bandar Baru sudah memiliki karakteristik bahasa yang baik dalam memberikan bimbingan dan konseling terhadap siswa namun perlu adanya peningkatan guna menciptakan karakteristik bahasa guru BK yang lebih baik.

Pengunaan ungkapan verbal langsung aspek menyebutkan perasaan dan memberikan nama pada perasaan boleh digunakan jika penggunaan aspek tersebut menunjukkan rasa kagum atau senangnya guru BK terhadap siswa. Namun, jika penggunaan aspek tersebut menunjukkan rasa tidak senang guru BK terhadap siswa lebih baik tidak digunakan karena dapat membuat siswa semakin menuju hal yang bersifat negatif. Hal yang bersifat negatif tersebut misalnya siswa semakin nakal, jahat, malu, dan tidak menghargai orang lain.

\section{Menggunakan Kiasan Perasaan}

Penggunaan kiasan perasaan dalam tuturan guru BK pada SMP Kecamatan Bandar Baru, Kabupaten Pidie Jaya belum memenuhi kriteria. Dari keempat data yang telah dianalisis, tuturan guru BK pada SMP Kecamatan Bandar Baru, Kabupaten Pidie Jaya tidak menggunakan ungkapan verbal langsung aspek kiasan perasaan dalam proses memberikan bimbingan dan konseling terhadap siswa. Aspek menggunakan kiasan perasaan sebaiknya digunakan guna memperhalus bahasa dalam proses bimbingan dan konseling.

\section{Menunjukkan Bentuk Tindakan yang Ingin Dilakukan}

Berdasarkan keempat data yang telah dianalisis ditemukan satu tuturan guru BK yang menggunakan aspek menunjukkan bentuk tindakan yang ingin dilakukan dalam proses pemberian bimbingan dan konseling terhadap siswa. Penggunaan aspek tersebut ditemukan pada contoh (1) data tiga. Dalam contoh (1) tersebut guru BK menyatakan bahwa seandainya 
anak didiknya mengulangi lagi perbuatan yang sama maka guru BK akan menampar anak didiknya.

Penggunaan aspek tersebut digunakan karena guru BK tidak menginginkan siswanya mengulangi lagi perbuatannya yang tidak baik. Penggunaan aspek tersebut sebaiknya tidak digunakan guru BK dalam memberikan bimbingan dan konseling terhadap siswa karena dapat memperburuk karakter siswa. Jadi, berdasarkan hasil analisis data secara garis besar karakteristik bahasa guru BK pada SMP Kecamatan Bandar Baru, Kabupaten Pidie Jaya aspek menunjukkan bentuk tindakan yang ingin dilakukan sudah baik namun perlu adanya peningkatan.

\section{Menggunakan Kiasan Kata-kata}

Dari keempat data yang sudah dianalisis tidak ditemukan ungkapan verbal langsung aspek menggunakan kiasan kata-kata dalam tuturan yang dihasilkan guru BK pada saat memberikan bimbingan dan konseling terhadap siswa. pengguanaan aspek tersebut sebaiknya digunakan guna memperhalus dan memperkaya bahasa. Dengan tidak ditemukan aspek tersebut dapat disimpulkan bahwa karakteristik bahasa guru BK pada SMP Kecamatan Bandar Baru, Kabupaten Pidie Jaya masih kurang baik dan perlu adanya peningkatan guna menciptakan suasana yang harmonis antara guru dan siswa.

\section{Jenis-jenis Ungkapan Verbal tidak Langsung Mencap atau Memberikan Cap Verbal}

Berdasarkan keempat data yang telah dianalisis tidak ditemukan satu tuturan guru BK yang menggunakan ungkapan verbal tidak langsung aspek mencap atau memberikan cap verbal dalam memberikan bimbingan dan konseling terhadap siswa. Penggunaan aspek mencap atau memberikan cap verbal tidak perlu digunakan guru BK dalam memberikan layanan bimbingan dan konseling karena penggunaan aspek tersebut dapat membuat siswa semakin bersifat buruk. Dengan tidak ditemukan aspek tersebut dalam keempat data yang telah dianalisis maka dapat disimpulkan bahwa bahasa guru BK sudah memiliki karakteristik bahasa yang sangat baik dan perlu dipertahankan.

\section{Memerintah}

Dari keempat data yang telah dianalisis peneliti menemukan ungkapan verbal langsung aspek memerintah dalam tuturan guru BK pada saat memberikan bimbingan dan konseling.

Data satu ditemukan 13 contoh tuturan aspek memerintah yang digunakan guru BK. Data dua ditemukan 7 contoh tuturan aspek memerintah yang digunakan guru BK. Data tiga ditemukan 27 tuturan aspek memrintah yang digunakan guru BK. Dan data empat ditemukan 18 tuturan aspek memerintah yang digunakan guru BK dalam memberikan bimbingan dan konseling terhadap siswa.

Dari semua jumlah tuturan aspek memerintah yang digunakan guru BK ada beberapa tuturan yang bersifat lembut dan sopan yang digunakan guru BK pada saat memberikan bimbingan dan konseling terhadap siswa. Penggunaan aspek memerintah yang bersifat kasar disebabkan oleh sikap siswa yang tidak baik. Jadi, berdasarkan hasil analisis data dapat disimpulkan bahwa tuturan guru BK pada SMP Kecamatan Bandar Baru, Kabupaten Pidie Jaya aspek memerintah sudah memiliki karakteristik bahasa yang baik namun perlu ditingkatkaan.

\section{Bertanya}

Berdasarkan data yang diperoleh, ditemukan sejumlah ungkapan verbal tidak langsung aspek bertanya dalam tuturan guru BK pada saat memberikan bimbingan dan konseling terhadap siswa. Data satu ditemukan 44 tuturan guru BK aspek bertanya, data dua ditemukan 25 tuturan guru BK aspek bertanya, data tiga ditemukan 73 tuturan aspek bertanya, dan data empat ditemukan 25 tuturan guru BKaspek bertanya. Dari semua jumlah tuturan guru BK yang digunakan pada saat memberikan bimbingan dan konseling terhadap siswa ada sebagian tuturan yang menggunakan bahasa yang lembut dan sopan dan ada juga sebagian yang menggunakan kata yang kasar. Namun, penggunaan yang bersifat kasar disebabkan oleh sikap siswa dan faktor lingkungan guru yang kurang baik.

Penggunaan aspek bertanya harus betulbetul diperhatikan jenis bahasa seperti apa yang harus digunakan guru BK dalam memberikan bimbingan dan konseling terhadap siswa guna menciptakan proses bimbingan dan konseling yang baik. Jadi, berdasarkan hasil analisis data dapat dikatakan bahwa karakteristik bahasa guru BK pada SMP Kecamatan Bandar Baru, Kabupaten Pidie Jaya sudah baik dan perlu adanya peningkatan. 


\section{Menuduh}

Dari keempat data yang sudah dianalisis ditemukan satu tuturan ungkapan verbal tidak langsung aspek menuduh yang digunakan guru BK pada SMP Kecamatan Bandar Baru, Kabupaten Pidie Jaya dalam memberikan bimbingan dan konseling terhadap siswa. Tuturan guru BK aspek menuduh terdapat pada contoh (1) data tiga. Dalam tuturan tersebut guru BK menyatakan bahwa setiap anak didiknya ada membuka mulut dan kelihatan gigi maka dikatakan anak didiknya sudah menertawakan temannya.

Penggunaan aspek menuduh dalam tuturan guru BK pada saat memberikan bimbingan dan konseling sebaiknya dihindari sepenuhnya karena dapat berdampak negatif bagi siswa. Jadi, berdasarkan data yang ditemukan tersebut dapat disimpulkan bahwa guru BK pada SMP Kecamatan Bandar Baru, Kabupaten Pidie Jaya secara garis besar sudah memiliki karakteristik bahasa yang baik dilihat dari aspek menuduh, namun perlu namun perlu peningkatan.

\section{Menyindir}

Berdasarkan data yang diperoleh, ditemukan tiga tuturan guru BK pada SMP Kecamatan Bandar Baru, Kabupaten Pidie Jaya yang menggunakan ungkapan verbal tidak langsung aspek menyindir. Tuturan guru BK aspek menyindir ditemukan pada contoh (1) dan (2) data dua dan pada contoh (1) data tiga. Tuturan guru BK pada contoh (1) menggunakan aspek menyindir yang menyatakan "Nan lagak deh" dan contoh (2) guru BK menyatakan "Aneuk teungku lom" dalam artian namanya bagus sekali, anak ustad lagi tetapi kenapa akhlaknya tidak sebagus nama dan pekerjaan orang tuanya. Hal ini serupa dengan contoh (1) data tiga yang menyatakan "Aneuk pramuka" dalam artian siswa yang ikut dalam kegiatan pramuka.

Penggunaan aspek menyindir itu dilakukan karena gurunya merasa kesal atau kecewa dan juga disebabkan karena faktor guru itu sendiri yang suka menyindir. Penggunaan aspek menyindir seharusnya tidak digunakan guru BK dalam meberikan layanan bimbingan dan konseling terhadap siswa karena dapat berdampak negatif bagi sikap dan perilaku siswa. Jadi, berdasarkan data tersebut dapat disimpulkan bahwa guru BK pada SMP Kecamatan Bandar Baru, Kabupaten Pidie Jaya belum memiliki karakteristik bahasa yang baik.

\section{Memuji}

Berdasarkan keempat data yang sudah dianalisis ditemukan dua tuturan guru BK ungkapan verbal tidak langsung aspek memuji yang digunakan dalam memberikan bimbingan dan konseling terhadap siswa. Tuturan guru BK aspek memuji ditemukan pada contoh (1) data tiga dan contoh (1) data empat. Contoh (1) data tiga menunjukkan adanya aspek memuji ketika guru BK memberikan bimbingan terhadap siswanya. Dalam tuturan (1) data tiga tersebut guru BK menyatakan pujiannya kepada anak didik dengan ungkapan "Subhanallah". Berdarkan data tersebut dapat dikatakan bahwa guru BK merasa senang dan bahagia dengan sifat yang dimiliki siswanya.

Selanjutnya contoh (1) data empat menunjukkan bahwa adanya aspek memuji yang digunakan guru BK dalam meberikan bimbingan dan konseling terhadap siswa. Hal tersebut dapat dilihat langsung dalam tuturan guru BK yang menyatakan "Martunis, ok. Bagus". Penggunaan ungkapan tersebut juga dilakukan guru BK karena anak didiknya sudah berjanji tidak akan libur sekolah lagi tanpa keterangan.

Penggunaan aspek memuji memang harus digunakan oleh guru BK dalam memberikan bimbingan dan konseling terhadap siswa guna menciptakan hubungan yang harmonis dengan siswa. Jadi, berdasarkan hal tersebut dapat dikatakan bahwa karakteristik bahasa guru BK pada SMP Kecamatan Bandar Baru Pidie Jaya dilihat dari aspek memuji masih kurang baik dan perlu banyak peningkatan.

\section{Mencela}

Ditemukan enam tuturan guru BK menggunakan ungkapan verbal langsung aspek mencela dalam memberikan bimbingan dan konseling terhadap siswa. Tuturan guru BK aspek mencela ditemukan pada contoh (1) data dua, contoh (1), (2), (3), dan (4) data tiga, dan pada contoh (1) data empat. Contoh (1) data dua menunjukkan guru BK menggunakan aspek menceal dengan mengatakan perbuatan siswanya yang sudah keterlaluan dan sudah termasuk pelecehan seksual. Contoh (1), (2), (3) dan (4) menunjukkan guru BK menggunakan aspek mencela dengan menggunakan tuturantuturan yang kurang mendidik. Sama halnya dengan contoh (1) data empat guru BK juga menyatakan kepada siswanya bahasa sendiri tidak tau.

Berdasarkan data tersebut terlihat jelas bahwa guru BK pada SMP Kecamatan Bandar 
Baru, Kabupaten pidie Jaya menggunakan aspek mencela dalam melakukan bimbingan dan konseling terhadap siswa. Penggunaan aspek mencela dalam tuturan guru BK pada saat memberikan bimbingan dan konseling terhadap siswa tersebut disebabkan karena gurunya memiliki latar belakang yang sedikit kasar. Penggunaan aspek mencela sebaiknya tidak digunakan guru BK dalam memberikan bimbingan dan konseling terhadap siswa karena guru merupakan cerminan sikap atau akhlak bagi siswa. Jadi, berdasarkan hasil analisis data dapat disimpulkan bahwa karakteristik bahasa guru BK kurang baik dan perlu peningkatan.

\section{Memakai Sebutan}

Berdasarkan data yang diperoleh, ditemukan satu tuturan guru BK yang menggunakan ungkapan verbal langsung aspek memakai sebutan. Tuturan guru BK asppek memakai sebutan ditemukan pada contoh (1) data tiga. Dalam contoh (1) tersebut guru BK mengatakan "Miss lebai" kepada anak didiknya. Penggunaan aspek memakai sebutan tersebut digunakan karena gurunya memiliki latar belakang bahasa yang kurang baik. Penggunaan aspek tersebut sebaiknya tidak digunakan karena dapat berdampak negatif terhadap sifat siswa.

Jadi, berdasarkan hal yang telah dikemukakan di atas dapat disimpulkan bahwa karakteristik bahasa guru BK pada SMP Kecamatan Bandar Baru Pidie Jaya sudak baik namun perlu peningkatan.

\section{Simpulan}

Berdasarkan hasil analisis data dapat disimpulkan bahwa guru BK pada SMP Kecamatan Bandar Baru Kabupaten Pidie Jaya memiliki karakteristik bahasa yang baik dalam hal pemberian layanan bimbingan dan konseling terhadap siswa. Karakteristik bahasa guru BK itu sendiri terdiri dari ungkapan verbal langsung dan ungkapan verbal tidak langsung. Ungkapan verbal langsung terdiri atas empat aspek, yaitu: 1) menyebutkan perasaan dan memberikan nama pada perasaan; 2) menggunakan kiasan perasaan; 3) menunjukkan bentuk tidakan yang ingin dilakukan; 4) menggunakan kiasan katakata. Namun, dari keempat aspek tersebut ada dua aspek ungkapan verbal langsung yang ditemukan peneliti dalam penelitian ini, yaitu 1) aspek menyebutkan perasaan dan memberikan nama pada perasaan, dan 3) aspek menunjukkan bentuk tindakan yang ingin dilakukan sedangkan aspek 2) dan 4) tidak ditemukan. Berdasarkan penemuan dua aspek ungkapan verbal langsung yang digunakan guru BK dalam pemberian layanan bimbingan dan konseling terhadap siswa dapat dikatan bahwa karakteristik bahasa guru BK dari segi ungkapan verbal langsung sudah baik namun perlu peningkatan seperti penggunaan aspek 2) dan 4) seharusnya digunakan.

Ungkapan verbal tidak langsung terdiri atas delapan aspek, yaitu 1) mencap atau memberikan cap verbal; 2) memerintah; 3) bertanya; 4) menuduh; 5) menyindir; 6) memuji; 7) mencela; dan 8) memakai sebutan. Dari Kedelapan aspek ungkapan verbal tidak langsung tersebut peneliti menemukan tujuh aspek ungkapan verbal langsung yang digunakan guru BK dalam pemberian layanan bimbingan dan konseling terhadap siswa. Dari tujuh aspek ungkapan verbal tidak langsung tersebut seharusnya guru BK hanya menggunakan tiga aspek saja sedangkan lima aspek lainnya tidak perlu digunakan karena dapat berdampak negatif bagi siswa. Jadi, berdasarkan hasil analisis data pada bab IV dapat dikatakan bahwa karakteristik bahasa guru BK pada SMP Kecamatan Bandar Baru Kabupaten Pidie Jaya dari segi penggunaan ungkapan verbal tidak langsung sudah baik namun perlu banyak peningkatan guna mencapai hasil yang lebih maksimal.

\section{Saran}

Mengingat penelitian ini belum mengkaji semua aspek dari tuturan yang dihasilkan guru BK, maka disarankan hal-hal sebagai berikut.

1) Penelitian ini hanya mengkaji karakteristik bahasa guru BK pada SMP Kecamatan Bandar Baru, Kabupaten Pidie Jaya. Diharapkan kepada peneliti selanjutnya untuk dapat mengkaji karakteristik bahasa guru BK pada Provinsi Aceh.

2) Hasil penelitian ini diharapkan dapat menjadi bahan pembelajaran bagi guru BK lainnya.

3) Penelitian ini belum komprehensif karena hanya mengkaji karakteristik bahasa guru BK. Disarankan kepada peneliti selanjutnya untuk dapat 
mengkaji makna-makna yang terkandung di dalam tuturan guru BK.

\section{DAFTAR PUSTAKA}

Baraja, Abubakar. 2004. Psikologi Konseling dan Teknik Konseling. Jakarta Timur: Studio Press.

Chaer, Abdul. 2003. Linguitik Umum. Jakarta: PT Rineka Cipta.

Dardjowidjojo, Soejono. 2005. Psikolinguistik Pengantar Pemahaman Manusia. Jakarta: Yayasan Obor Indonesia.

Darma, Yoce Aliah. 2009. Analisis Wacana Kritis. Bandung: CV. Yrama Widia.

Depdiknas. 2005. Kamus Besar Bahasa Indonesia. Jakarta: Balai Pustaka.

Dirgantara, Yuana Agus. 2012. Pelangi Bahasa Sastra dan Budaya Indonesia. Yogyakarta: Garudhawaca Digital Book and POD.

Fatimah. 1994. Wacana Pemahaman dan Hubungan Antarunsur. Bandung: PT ERESCO.

Furqon, Arief.1982.Peneliti Dalam Pendidikan. Surabaya Usaha Nasional.

http://portal.kopertis3.or.id/bitstream/123456789 /749/1/konselor.pdf. unduh pada hari senin, 10 juni 2014. Pukul 09.30 wib.

http://repository.upi.edu/3087/6/T_LIN_110225 5_CHAPTER3.pdf sri. Jumat, 20 Juni 2014 pukul $20.00 \mathrm{wib}$

http.files.wordpress.com/2007/10/jurnapenelitianl-misa.doc. Selasa, 1 Juli 2014. Pukul 09.00 wib
Lesmana, Jeanette Murad. 2006. Dasar-Dasar Konseling. Jakarta: Universitas Indonesia.

Mahsun. 2005. Metode Penelitian Bahasa. Jakarta: PT RAJAGRAFIDO PERSADA.

Moleong. Metode Penelitian Kualitatif. 2007. Bandung: PT Remaja Rosdakarya.

Sardiman. 2012. Interaksi \& Motivasi Belajar Mengajar. Jakarta: PT RajaGrafindo Persada.

Setiawati, Nanik. 2010. Analisis Kesalahan Berbahasa Indonesia. Surakarta: Yuma Pustaka.

Sudaryat, Yayat. 2009. Makna dalam Wacana. Bandung: CV. Yrama Widya.

Sugiono. 2010. Metode Penelitian Pendidikan Pendekatan Kuantitatif, Kualitatif, dan $R \& D$. Bandung: Alfabeta.

Sumarsono dan Paina Partana. 2004. Sosilinguistik. Yogyakarta: SABDA

Tarigan, Guntur. Pengajaran Wacana. 1987. Bandung: Angkasa.

Winkel, W.S \& M.M Srihastuti. 2007. Bimbingan dan Konseling di Institut Pendidikan. Yogyakarta: Penerbit Media Abadi.

Yusuf, Samsu dan Juntika Nurishan. 2006. Landasan Bimbingan dan Konseling. Bandung: PT Remaja Rosdakarya. 